\title{
Evaluating the Provision of Information in the Financial Statements of Enterprises: Empirical Evidence From Vietnam*
}

\author{
Thinh Tran Quoc \\ Banking University of Ho Chi Minh City, Vietnam
}

\begin{abstract}
Globalization trend has raised demand for establishing a consistent legal framework internationally. Vietnam has been establishing gradually a consistent legal framework according to countries in the world for improving information in financial statements of enterprises. Timely, the Ministry of Finance has made a great effort to publish the draft to correct and adjust accounting laws, accounting standards, and accounting systems to improve and enhance the quality of accounting information. However, based on the result of experiment survey including auditors, chief accountants, and investors, the information in the financial statements provided by Vietnamese enterprises has some shortcomings. The information provided by organizations has not satisfied the demand of users to make useful decisions. Ideally, Vietnam needs to have certain improvements in overall by state, enterprises, and occupation organizations to provide information with high quality and accuracy. This in turn will be crucial for Vietnam in international accounting integration progress.
\end{abstract}

Keywords: accounting information, information quality, financial statement, Vietnamese accounting, Vietnamese enterprises

\section{Introduction}

The quality of information in the financial statements is important because the users make business decisions through assessment and analysis of the information provided in the financial reports. Nowadays, not only providing numbers, but accounting information also ensures the quality to satisfy the demand of users in the financial market. In recent years, Vietnam has improved the quality of information when preparing financial reports; however, in reality, there are shortcomings in providing financial information by Vietnamese enterprises. The information provided by organizations has not satisfied the demand of users to make useful decisions. Ideally, Vietnam needs to have certain improvements in overall by state, enterprises, and occupation organizations to provide information with high quality and accuracy. It is crucial and important for Vietnam towards the international accounting integration as well as the conformity with the rules of countries all over the world.

\footnotetext{
* Acknowledgement: The author wishes to express the sincere gratitude to Associate Professor, Dr. Duc Huu Vu and to Associate Professor, Dr. Tan Tran Thi Giang for their helpful assistance and guidance. This paper was presented at the 3rd 2015 IBEA International Conference on Business, Economics, and Accounting.

Thinh Tran Quoc, Dr., lecturer of Division of Accounting, Faculty of Accounting and Auditing, Banking University of Ho Chi Minh City. Email: thinhtq@buh.edu.vn.
} 


\begin{abstract}
Aim of Study
From the view of state, companies, and occupation organizations, we aim to assess the information supply in the financial reports of Vietnamese enterprises to give effective solutions for improving the quality and increasing the usefulness of information to support users.
\end{abstract}

\title{
Method of Investigation
}

The methods used for investigation are: quantitative research methods that use statistical methods described (descriptive statistics), combined analysis of variance factor (one-way analysis of variance (ANOVA)), as well as methods for standard deviation smallest difference (least significant difference (LSD)) in testing the post hoc between the survey groups.

\section{The Previous Study and Hypothesis Development}

In the trend of global economic integration, the accounting information of enterprises has important implications in attracting economic resources abroad and inside the country. Therefore, the disclosure of information on the financial statements of companies has received the attention of many investors from different countries, occupation organizations, as well as professional researchers. Agyei-Mensah (2013) surveyed 35 listed companies to evaluate the quality of information disclosed in the financial statements based on the International Financial Reporting Standards (IFRS) of Ghana, and as a result, the quality of information has increased to $87.09 \%$ in 2009, compared to $76.8 \%$ in 2006. M. C. Milos and L. R. Milos (2014) also conducted a survey of 200 objects including analysts, creditors, and enterprises to consider presenting in the financial reports of Romania's businesses. According to the evaluation, the surveyed objects perceived that the provision of business information needs to be improved in both quality and quantity. Recently, Bassemir and Novotny-Farkas (2015) studied 273 German companies in the period from 1998 to 2010 to assess the quality of information and practical information on financial statements published by the enterprises. Besides, the evaluation of the quality of corporate financial statements has received the attention of the professional organizations, such as PwC (2013), KPMG (2014). It involves assessing the quality of information provided in the financial statements of the enterprises. The studies of Bonner (2008) and Alagoa (2015) focus on the evaluation from the third parties (shareholders, directors, managers, investment analysts, etc.). This shows the objectivity and independence of the recognized problem from many perspectives. The typical pioneering studies can be those of Klaassen and Schreuder (1981) and Vergoossen (1993), who tested the use of information and comments on different divisions of the financial statements between the groups using the information in the financial statements. The studies including Al-Mubarak (1997), Al-Gareh (2001), Al-Fayyoumi (2003), Abuzarour (2005), Abdelkarim and Shahin (2007), and Abdelkarim, Shahim, and Arqawi (2009) focus on the investors' assessment of the information provided by the business. Johansen and Plenborg (2013) evaluated the level of priority in the publication of information on the financial statements of the companies in Denmark. Similarly, the annual professional organizations have surveys to assess the quality of information in the financial statements of the enterprises such as International Federation of Accountants (IFAC, 2013), ICAEW (2014), etc.. In Vietnam, researches related to the presentation and providing accounting information on the financial statements of companies have also received some attentions from researchers. Micheline and Nguyen (2007) evaluated the quality of accounting information on the basis of assessment of the various objects after Vietnam issued some accounting standards. Result from the survey showed that 
information was presented in the financial statements which met the needs of comparison. However, the reliability of information was not high. Pham (2009) and Le (2010) evaluated the situation in the provision of information in the financial statements of listed companies and proposed completed solutions as well as enhanced the usefulness of information. Pham (2010) assessed that the level of harmonization in the measurement was $81.2 \%$ and the disclosure of information is $57 \%$. Tran (2014) assessed that the quality of information provided in the financial statements of the Vietnam enterprises now generally ensures certain requirements, but they have not satisfied the expectations of users.

It is possible that the studies focus on the information in the financial statements of the enterprises, a field where many comments from variance audiences exist. This is the basis for our overall assessment to propose the effective solution. From previous studies, the research issue is: assessments of the auditors, investors and board of directors, and chief/vice accountants about providing practical information on the financial statements of companies in Vietnam.

\section{Design of Study}

Research has been done using a Likert scale from 1 to 5 (1: Poor; 2: Fair; 3: Average; 4: Good; 5: Excellent). This research uses SPSS software (Version 16.0) to create data tables as the basis of analysis and evaluation.

The survey consists of three basic contents related to the satisfaction of the amount as well as the quality and usefulness of the information currently provided by the businesses.

This paper selected 377 subjects that used directly or indirectly related to accounting standards, namely, the establishment (now) with 129 enterprises (34\%), users (investors) with 136 subjects (36\%), and auditors with 112 subjects (30\%). The subjects participated in the survey carried out in 2014 were focused mainly in the Ho Chi Minh City.

\section{Data Analysis}

Information provided in the financial statements for the users showed the quantity and quality of information as well as the usefulness of information in order to make decisions. This is the "product" and as an "output" of the enterprises in processing information. The results of questions about the information practically provided in the financial statements are presented in Table 1.

Table 1

Descriptive Statistics

\begin{tabular}{|c|c|c|c|c|c|c|c|c|c|}
\hline \multirow{2}{*}{ Item } & & \multirow{2}{*}{$N$} & \multirow{2}{*}{ Mean } & \multirow{2}{*}{$\begin{array}{l}\text { Std. } \\
\text { deviation }\end{array}$} & \multirow{2}{*}{ Std. error } & \multicolumn{2}{|c|}{ 95\% confidence interval for mean } & \multirow{2}{*}{ Minimum } & \multirow{2}{*}{ Maximum } \\
\hline & & & & & & Lower bound & Upper bound & & \\
\hline \multirow{4}{*}{ Item 1} & N1 & 112 & 2.91 & 0.679 & 0.064 & 2.78 & 3.04 & 1 & 4 \\
\hline & N2 & 136 & 2.94 & 0.777 & 0.067 & 2.81 & 3.07 & 1 & 4 \\
\hline & N3 & 129 & 3.18 & 0.551 & 0.049 & 3.08 & 3.27 & 2 & 4 \\
\hline & Total & 377 & 3.01 & 0.686 & 0.035 & 2.94 & 3.08 & 1 & 4 \\
\hline \multirow{4}{*}{ Item 2} & N1 & 112 & 2.75 & 0.753 & 0.071 & 2.61 & 2.89 & 1 & 4 \\
\hline & N2 & 136 & 2.78 & 0.841 & 0.072 & 2.64 & 2.92 & 1 & 5 \\
\hline & N3 & 129 & 2.73 & 0.737 & 0.065 & 2.60 & 2.86 & 1 & 5 \\
\hline & Total & 377 & 2.75 & 0.779 & 0.040 & 2.67 & 2.83 & 1 & 5 \\
\hline \multirow{4}{*}{ Item 3} & N1 & 112 & 2.92 & 0.725 & 0.068 & 2.78 & 3.06 & 1 & 4 \\
\hline & N2 & 136 & 2.81 & 0.812 & 0.070 & 2.67 & 2.95 & 1 & 5 \\
\hline & N3 & 129 & 2.65 & 0.767 & 0.068 & 2.52 & 2.78 & 1 & 4 \\
\hline & Total & 377 & 2.79 & 0.777 & 0.040 & 2.71 & 2.87 & 1 & 5 \\
\hline
\end{tabular}

Note. N1: auditors; N2: investors; N3: enterprises. 
Table 2

ANOVA

\begin{tabular}{|c|c|c|c|c|c|c|}
\hline Item & & Sum of squares & df & Mean square & $F$ & Sig. \\
\hline & Between groups & 5.398 & 2 & 2.699 & 5.885 & 0.003 \\
\hline \multirow[t]{3}{*}{ Item 1} & Within groups & 171.536 & 374 & 0.459 & & \\
\hline & Total & 176.934 & 376 & & & \\
\hline & Between groups & 0.172 & 2 & 0.086 & 0.141 & 0.868 \\
\hline \multirow[t]{3}{*}{ Item 2} & Within groups & 227.886 & 374 & 0.609 & & \\
\hline & Total & 228.058 & 376 & & & \\
\hline & Between groups & 4.415 & 2 & 2.208 & 3.709 & 0.025 \\
\hline \multirow[t]{2}{*}{ Item 3} & Within groups & 222.609 & 374 & 0.595 & & \\
\hline & Total & 227.024 & 376 & & & \\
\hline
\end{tabular}

Table 3

Multiple Comparisons

\begin{tabular}{|c|c|c|c|c|c|c|c|}
\hline \multicolumn{8}{|c|}{ Least significant difference (LSD) } \\
\hline \multirow{2}{*}{$\begin{array}{l}\text { Dependent } \\
\text { variable }\end{array}$} & \multirow{2}{*}{ (I) $\mathrm{N}$} & \multirow{2}{*}{ (J) $\mathrm{N}$} & \multirow{2}{*}{$\begin{array}{l}\text { Mean difference } \\
\text { (I-J) }\end{array}$} & \multirow{2}{*}{ Std. error } & \multirow{2}{*}{ Sig. } & \multicolumn{2}{|c|}{ 95\% confidence interval } \\
\hline & & & & & & Lower bound & Upper bound \\
\hline \multirow{6}{*}{ Item 1} & \multirow{2}{*}{ N1 } & N2 & -0.030 & 0.086 & 0.725 & -0.20 & 0.14 \\
\hline & & N3 & $-0.268^{*}$ & 0.087 & 0.002 & -0.44 & -0.10 \\
\hline & \multirow{2}{*}{ N2 } & N1 & 0.030 & 0.086 & 0.725 & -0.14 & 0.20 \\
\hline & & N3 & $-0.237^{*}$ & 0.083 & 0.005 & -0.40 & -0.07 \\
\hline & \multirow{2}{*}{ N3 } & N1 & $0.268^{*}$ & 0.087 & 0.002 & 0.10 & 0.44 \\
\hline & & N2 & $0.237^{*}$ & 0.083 & 0.005 & 0.07 & 0.40 \\
\hline \multirow{6}{*}{ Item 2} & \multirow{2}{*}{ N1 } & N2 & -0.029 & 0.100 & 0.768 & -0.23 & 0.17 \\
\hline & & N3 & 0.021 & 0.101 & 0.833 & -0.18 & 0.22 \\
\hline & \multirow{2}{*}{ N2 } & N1 & 0.029 & 0.100 & 0.768 & -0.17 & 0.23 \\
\hline & & N3 & 0.051 & 0.096 & 0.597 & -0.14 & 0.24 \\
\hline & \multirow{2}{*}{ N3 } & N1 & -0.021 & 0.101 & 0.833 & -0.22 & 0.18 \\
\hline & & N2 & -0.051 & 0.096 & 0.597 & -0.24 & 0.14 \\
\hline \multirow{6}{*}{ Item 3} & \multirow{2}{*}{ N1 } & N2 & 0.111 & 0.098 & 0.261 & -0.08 & 0.30 \\
\hline & & N3 & $0.268^{*}$ & 0.100 & 0.007 & 0.07 & 0.46 \\
\hline & \multirow{2}{*}{ N2 } & N1 & -0.111 & 0.098 & 0.261 & -0.30 & 0.08 \\
\hline & & N3 & 0.158 & 0.095 & 0.097 & -0.03 & 0.34 \\
\hline & \multirow{2}{*}{ N3 } & N1 & $-0.268^{*}$ & 0.100 & 0.007 & -0.46 & -0.07 \\
\hline & & N2 & -0.158 & 0.095 & 0.097 & -0.34 & 0.03 \\
\hline
\end{tabular}

Notes. ": The mean difference is significant at the level of 0.05. N1: auditors; N2: investors; N3: enterprises.

\section{Level of Satisfaction in Terms of the Amount of Information Provided in the Financial Statements for Decision-Making (Item 1)}

The question is how the satisfaction of the subjects on the amount of information provided in the financial statements and the data assessment of the target groups differ?

$\mathrm{H} 0$ : There is no difference between the groups in levels of satisfaction related to the amount of information provided.

H1: There is a difference between the groups in levels of satisfaction related to the amount of information provided. 
The results showed that the respondents acknowledged the amount of information provided to decision-making with an average rating of 3.01. This assessment shows that the amount of information provided today is acceptable, not really satisfied.

In the analysis of variance, it is showed that subjects considered the different assumptions about the amount of information provided (significance level of 0.03, see Table 2).

Later testing showed the average difference between the groups in which the lowest is auditors and the highest is enterprises, while investors underestimated the average rate. The role of auditors demands more to verify information, while enterprises, especially state-owned enterprises, seem to be happy with the amount of information provided. It is worth noting that investors who directly use financial statements are expecting more of the amount of information provided in the financial statements (see Table 3).

\section{Level of Satisfaction in Terms of Quality of the Information Provided in the Financial Statements for Decision-Making (Item 2)}

The question is that how the degree of satisfaction of the audience is about the quality of information provided in the financial statements for decision-making and that it is affordable significant differences in the assessment of the target group.

H0: There is no difference between the groups on the level of satisfaction concerning the quality of information provided.

H1: There is a difference between the groups on the level of satisfaction concerning the quality of information provided.

According to the survey, compared with the amount of information provided, the quality of information provided on the financial statements for making decisions was assessed by the respondents at the lowest level and each group of subjects is the average of 2.75 (see Table 1). This indicates that the objects are still disturbed with quality information at present.

According to the result of analysis of variance, the mean observed in terms of quality is 0.868 , greater than 0.05 (95\% confidence, see Table 2). Thus, the objects agree on this issue.

\section{The Level of General Usefulness of Information on Financial Reports for Decision-Making (Item 3)}

The question is that how the objects assess helpful information on financial reports for decision-making and whether there are differences between the groups on the level of consistency of Vietnamese accounting standards or not?

H0: There is no difference between the groups concerning the usefulness of the information provided.

H1: There is a difference between the groups concerning the usefulness of the information provided.

According to the evaluation, the level of usefulness of information on the financial statements for decision-making does not meet the requirements and is rated the lowest level (2.79) by subjects (see Table 1). Similar to the identification of objects on the quality of information, the level of usefulness of information does not guarantee against the requirements.

In the analysis of variance, it is showed that subjects have different assumptions about the extent to which useful information was provided (level of significance 0.025 , see Table 2).

Later testing showed that the average difference between the groups and the result was opposite to the level of assessment of satisfaction on the amount of information. This can be explained by the fact that the auditors with deep expertise in the profession should be able to recognize and evaluate the usefulness of the 
information provided rather than the organizations. In general, investors are the direct users of financial statements and their expectations are high in the level of usefulness of information in the financial statements (see Table 3).

\section{Results}

With the result of the analysis on the practical information provided in financial statements, there is a consensus in the comments of the surveyed subjects that the quality of information provided by businesses does not meet the requirements for decision-making, and the quality and usefulness of the information are limited. This was also noted by Micheline and Nguyen (2007), Pham (2010), and Tran (2014). The amount of information provided in general evaluation is higher (average values from 2.91 to 3.18) than the usefulness (the average level from 2.66 to 2.92). However, in each content related to the amount of information or usefulness, the optimistic bias occurs for corporate organizations or auditors, rather than investors who use the information.

\section{Solutions}

From the results above, to provide information on the financial statements of businesses and ensure the quality as well as enhance the usefulness of information, some basic measures should be implemented synchronously and uniformly as follows.

\section{From the State}

The Ministry of Finance needs to enhance the role of the State Securities Commission to have the sanctions for public companies, in particular, listed companies, to contribute to the improvement of the quality and usefulness of information and satisfy the needs of investors.

At the same time, the state agency should propagate to raise the awareness of the enterprise management, especially joint-stock companies to fully implement the obligations and responsibilities in providing information to users.

In the long term, to improve the management and control, the Ministry of Finance generally needs to establish organizations with authorities to supervise the disclosure of information of businesses. This helps to improve the soundness and transparency of information for businesses and ensure benefits for investors in particular and other users in general for making business decisions.

\section{Enterprises}

Managers need to be aware of the importance of complying with the provisions relating to the presentation and disclosure of information.

Businesses need to improve the obligation and responsibility to provide information to ensure transparency and honesty to users.

\section{Occupation Organization}

The organizations need to train accountants to improve their professional skills. Besides, this organization regularly trains accountants how to implement the presentation and provide information with the current regulations.

In addition, professional associations need to update the regulations, new accounting regime, particularly relating to the presentation and disclosure of information to timely support businesses. 


\section{Conclusion}

In the economic development trend of regional and international integration, demand for providing information of businesses is significant and practical to make information transparent and fair on the financial statements. In thinking, Vietnam, a developing country, should have consistent orientation combination of synchronous solutions to improve the quality of information. Accordingly, the coordination of state, enterprises, and the professional organizations is necessary. They must create a legal framework to bring uniformity and consistency on the basis of the principles, general accounting rules in compliance with the international standards and practices of the countries in the world. Monitoring organizations are also established to supervise for providing information on the financial statements of the business, especially for public companies, improving infrastructure for training accountants; increasing the awareness of businesses about obligations and responsibilities in providing information to users. This is one of the key issues which contribute to the improvement of the quality of information in order to attract foreign investments, increase value of financial market to satisfy the strategy of domestic economic development with the trend of economic integration regionally and internationally.

\section{References}

Abdelkarim, N., \& Shahin, Y. (2007). Empirical testing of the informational efficiency of Palestine Securities Exchange. Working Paper.

Abdelkarim, N., Shahim, Y. A., \& Arqawi, B. M. (2009). Investor perception of information disclosed in financial reports of Palestine Securities Exchange listed companies. Accounting and Taxation, 1(1), 45-61.

Abuzarour, B. (2005). The effect of infrequent trading on market efficiency: The case of the Middle East stock markets. Working Paper, Department of Business Administration, Patra University Campus, Greece.

Agyei-Mensah, B. K. (2013). Adoption of International Financial Reporting Standards (IFRS) in Ghana and the quality of financial statement disclosures. International Journal of Accounting and Financial Reporting, 3(2), 269-286.

Alagoa, H. E. (2015). Approaches used by third party users to assess accounting information and evaluate the judgment and decision making (JDMs) of accounting professionals. Retrieved from http://papers.ssrn.com/sol3/papers.cfm?abstract_id=2564635

Al-Fayyoumi, N. (2003). Information arrival, trading volume, and price variability: An applied study on the Palestinian Securities Exchange. Yarmouk University Journal, 19(2A), 55-68.

Al-Gareh, B. (2001). Stock price behavior in emerging markets: An empirical study on Palestine Securities Exchange (Unpublished master dissertation, Jordanian University, Jordan).

Al-Mubarak, F. (1997). The usefulness of corporate annual reports to investment analysts in Saudi Arabia (Unpublished doctoral dissertation, University of Newcastle, Newcastle).

Bassemir, M., \& Novotny-Farkas, Z. (2015). IFRS adoption, reporting incentives, and financial reporting quality in private firms. Retrieved from http://papers.ssrn.com/sol3/papers.cfm?abstract_id=2446585

Bonner, S. E. (2008). Judgment and decision making in accounting. Upper Saddle River, NJ: Pearson/Prentice Hall.

ICAEW. (2014). The effects of mandatory IFRS adoption in the EU: A review of empirical research. Retrieved from http://www.icaew.com/en/technical/financial-reporting/information-for-better-markets/ifbm-reports/the-effects-of-mandatory-if rs-adoption-in-the-eu

International Federation of Accountants [IFAC]. (2013). Financial reporting supply chain. Retrieved from http://www.ifac.org/news-events/2013-11/ifac-council-seminar-discusses-financial-reporting-supply-chain

Johansen, T. R., \& Plenborg, T. (2013). Prioritising disclosures in the annual report. Accounting and Business Research, 43(6), 605-635.

Klaassen, J., \& Schreuder, H. (1981). Corporate report readership and usage in the Netherlands. Maandblad voor Accountancy en Bedreifshuishoudkunde. Amsterdam, 55(2/3), 101-117.

KPMG. (2014). The KPMG survey of business reporting. Retrieved from http://www.kpmg.com/global/en/issuesandinsights/articlespublications/pages/kpmg-survey-business-reporting.aspx 
Le, X. T. T. (2010). The useful information of accounting to make a decision for investors in Vietnam security market (Master thesis, Ho Chi Minh Economic University).

Micheline, R., \& Nguyen, C. P. (2007). The new system of business accounting in Vietnam: An empirical valuation. Retrieved from http://www.lautorite.qc.ca/files/pdf/fonds-education-saine-gouvernance/promo-gouvernance/cifo-esg-uqam-etude-2007-03.pdf

Milos, M. C., \& Milos, L. R. (2014). A survey regarding the quality of financial statement. Annales Universitatis Apulensis Series Oeconomica, 16(2), 221-228.

Pham, H. H. (2010). De-jure convergence between Vietnamese and international accounting standard. Science and Technology Journal. Da Nang University No. 5(40).

Pham, T. D. (2009). The solution to complete disclosing accounting information for listed company in Vietnam security market (Master thesis, Ho Chi Minh Economic University).

PwC. (2013). Global IPSAS survey: Towards a new era in government accounting and reporting. Retrieved from http://www.pwc.com/gx/en/psrc/publications/government-accounting-and-reporting-pwc-global-ipsas-survey.jhtml

Tran, T. Q. (2014). Trend to build Vietnamese financial repot standard to satisfy international accounting convergence (Ph.D. thesis, Ho Chi Minh Economic University).

Vergoossen, R. G. A. (1993). The use and perceived importance of annual reports by investment analysts in the Netherlands. European Accounting Review, 2(2), 219-244. 